\title{
Assessment of Residents' Understanding of Potential Ecosystem Services of Phewa Watershed
}

\author{
Shivaraj Thapa ${ }^{1}$, Subina Shrestha ${ }^{1}$, Suman Bhattarai ${ }^{2}, 3$, \\ Mahamad Sayab Miya', Deepak Gautam ${ }^{2,4 *}$ \\ ${ }^{1}$ Beijing Forestry University, School of Economics and Management, Beijing, 100083, China \\ ${ }^{2}$ Tribhuvan University, Institute of Forestry, Pokhara Campus, Pokhara, 33700, Nepal \\ ${ }^{3}$ Beijing Forestry University, School of Forestry, Beijing, 100083, China \\ ${ }^{4}$ Beijing Forestry University, School of Ecology and Nature Conservation, Beijing, 100083, China \\ *Corresponding author:dgautam@iofpc.edu.np
}

\section{Abstract}

Phewa watershed, the second largest natural lake system in Nepal, is considered vital for the well being and economy at local, provincial and national level. Phewa watershed offers multiple benefits to the downstream dwellers involved in tourism, hotel, boating, fishing, irrigation, hydropower, etc. The constant degradation of watershed has become a serious challenge to sustain the watershed. Payment for Ecosystem Services (PES) can be an effective environmental management tool for sustaining ecological and economic benefits, especially in an urban watershed like Phewa. This study has assessed the opportunities for the potentiality of PES in Phewa watershed. It first identified and ranked the tradable ecosystem services along with service providers and beneficiaries using Likert scale. Then, 137 households were surveyed to evaluate their perceptions of payment for ecosystem services and sustainable management of Phewa Lake. The results identified tourism as the major ecosystem service in the watershed followed by biodiversity and sediment retention to control flooding and erosion. Protected and community forests users groups within the watershed area, landowners, and farmers were identified as upstream users or service providers whereas the business owners like boat agencies, hotels and restaurants, drinking water users, and Nepal electricity authority were identifiedas the service beneficiaries of the identified ecosystem service. The challenges associated with implementing PES scheme were the lack of financial resource, lack of institutional organization and marketing for ecosystem services, population growth, lack of coordination between stakeholders, and lack of public participation. Thus, this study showed that education-based activities should be organized to enhance participation of beneficiaries and upstream dwellers. Also, PES policy mechanism with clear guidelines should be formulated for assuring the participation of the community people forthe implementation of PES.

Keywords : Payment for environmental services; service provider; service beneficiaries; tourism

\section{Introduction}

Payment for ecosystem service (PES) is defined as a "voluntary transaction between service users and service providers, subject to agreed rules for the management of natural resource for generation of offsite services" (Wunder, 2014). Ecosystem Services are the benefits that people obtain from ecosystems. Ecosystem provides a wide range of goods and services that are beneficial to human kind (MEA, 2005). Ecosystem services include provisioning services (food, water, and timber), regulating services (climate, diseases, wastes and water quality), supporting 
services (soil formation, photosyn thesis and nutrient cycling) and cultural services (recreational, aesthetic and spiritual benefit) (Costanza et al., 1997; Costanza et al., 2014; MEA, 2005). In PES mechanism, different ecosystem functions are considered as ecosystem services, and these services are assigned monetary valuation for transitioning into payment scheme (Baggethun et al., 2010). The PES scheme must have at least one environmental service, at least one service buyer, also known as a consumer, and at least one service provider. PES will only operate if the institution has open ability, i.e. where resources, access and ownership are not in dispute (Pagiola et al., 2004). The definition of PES has developed in recent days from a strictly market-based approach to a tool used as a development scheme that promotes twin objectives of conservation and growth (Wunder, 2008). The definition of PES has changed a lot from Wunder's original definition (2005), which involves transaction between service provider and buyer. The experts now recognize the need for governments, donors and civil society to be active stakeholders and right holders in such transactions as to establish new markets and associated institutions (Vatn, 2010).

PES becomes an alternative financing mechanism for conservation programs in developing countries including Nepal in order to sustain natural resources (Kolinjivadi et al., 2015). The first implemented PES scheme for a watershed in Nepal was astudy conducted by Khatri (2009) in
Kulekhani watershed, to compensate and reward the upstream community of the watershed. The PES scheme has had a positive impact on the livelihoods of upstream communities and has helped reduce sedimentation in Kulekhani reservoir (Khatri, 2009). In a developing country like Nepal, it is difficult to adopt a market-based PES mechanism due to lack of government support, lack of resources and awareness (Fauzi and Anna, 2013). Therefore a number of PES like schemes are more popular in order to increase social benefit including payment for sediment retention in Phewa watershed (Bhatta et al., 2014; Khanal and Regmi, 2015; Thapa, 2016). The main aim of the sediment retention of the PES scheme in Phewa watershed is to explore potential methods to retain sediment in the upper catchment by establishing PES, support to sustain lake dependent tourism and improve livelihood of the upstream communities by ensuring conservation-friendly land use practices (Khanal and Regmi, 2015; Aryal et al., 2019).

Phewa Lake, important source for local livelihoods, has offered over US\$ 43 million per year from the ecosystem services such as tourism, hydroelectricity, irrigation, fishery, boating, and scenic beauty, out of which about $95 \%$ are associated with tourism and recreation (Kanel, 2010). The lake's ecosystem services are fragile, directly affecting the living condition of the lake dependent households (Paudyal et al., 2017). Though improvement in forest condition has slightly increased ecosystem services like sediment 
retention, carbon stocks, habit at provision and availability of raw material (Paudyal et al., 2019), threats like sedimentation, waste disposal, sewage drainage into the lake, invasion, reduced water discharge and eutrophication are still existing (Khanal and Regmi, 2015; Paudyal et al., 2018; Paudyal et al., 2019). Therefore, it has become crucial that upstream communities develop willingness to undertake activities and pay off lake-dependent people and all the stakeholders, especially the upstream and downstream communities, have consensus on mechanism of payment for ecosystem services.

The essence of this research lies in knowing the coping strategies to maintain balance between upstream and downstream communities. So, it explored the potentiality of payment for ecosystem services in Phewa Lake, building on the knowledge of PES, and explored opportunities and challenges of PES implementation in Phewa Watershed. This study aimed to answer the following key questions: (1) What are the available ecosystem services? (2) Who are the buyers, sellers and intermediaries in PES mechanism? (3) What is the perception of respondents towards PES program in Phewa Lake? And (4) How potential are ecosystem services provided by upstream land managers and used by downstream users. In doing so, it has explored potentiality of PES and provides guidance for PES scheme in the watershed.

\section{Materials and Methods}

\section{Study Area}

The study was conducted in Phewa watershed (Figure 1), which is the second largest lake system in the country which lies in Kaski district of Gandaki Province. Phewa watershed is the major source of drinking water for Pokhara Metropolitan area. Besides, it provides several other services like tourism, hydro-power, irrigation and climatic balance (Paudyal et al., 2018).

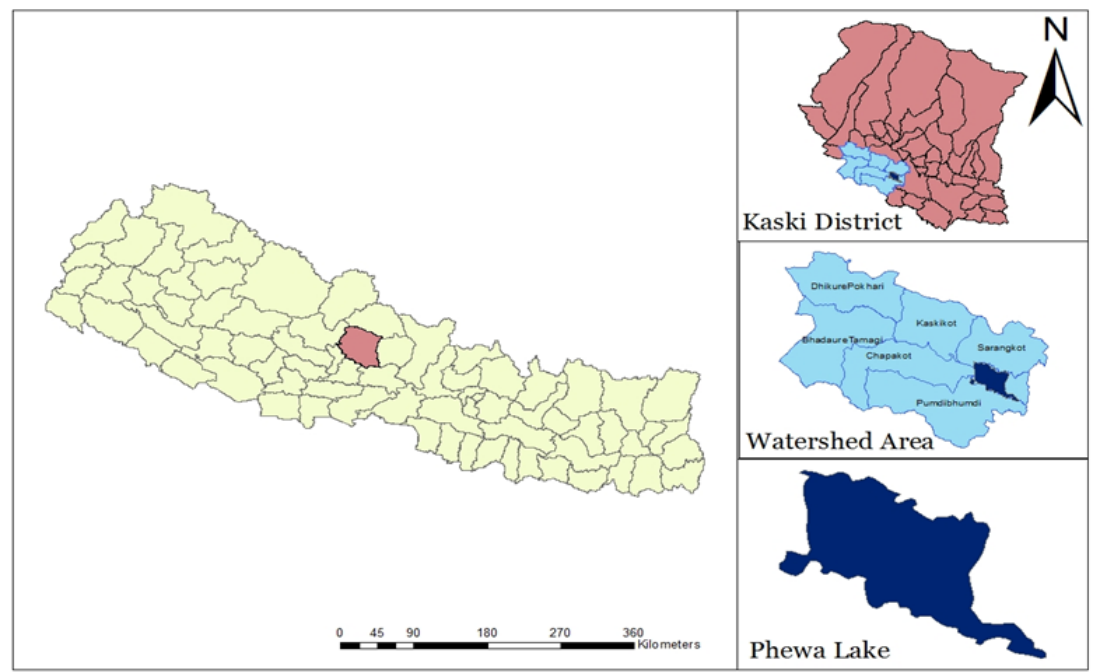

Figure 1: Location Map of Phewa Watershed and Phewa Lake in Kaski district of Nepal 
The watershed feeds Phewa Lake, which is the major attraction of tourists (WWF Nepal, 2014; Regmi and Saha, 2015). This lake is one of the places most visited by domestic and international tourists in Nepal (WWF Nepal, 2014). The watershed lies between $28^{\circ} 11^{\prime} 39^{\prime \prime}$ to $28^{\circ} 17^{\prime} 25^{\prime \prime}$ latitudes and $83^{\circ} 47^{\prime} 51^{\prime \prime}$ to $83^{\circ} 59^{\prime} 17^{\prime \prime}$ longitudes, near Pokhara Metropolitan City (PMC). The surface area of the watershed is $123 \mathrm{~km}^{2}$ (Paudyal et al., 2017) and spreads over the part of six villages (PumdiBhumd, Chapakot, Bhadaure Tamagi, Dhikur pokhari, Kaskikot and Sarangkot). Note: Now these villages come under Annapurna Rural Municipality (ARM) and Pokhara Metropolitan (PMC).

The Phewa Lake occupies $4.43 \mathrm{~km}^{2}$ with depth ranging from $8.6 \mathrm{~m}$ to $19 \mathrm{~m}$, which has been estimated to cover $3.3 \%$ of the watershed area (Leibundgut et al., 2016; Devkota et al., 2018). The watershed lies in a moist sub-tropical zone with annual rainfall 4500-5000 $\mathrm{mm}$ and annual water temperature ranging from 12-29 degree Celsius (Rai, 2000; Leibundgut et al., 2016). More than $80 \%$ of the annual precipitation occurs between the months of June to September. More than $60 \%$ of forests (2739 hectares) is under community-based forest management system (CBFM), which is managed by 75 community forest user groups (CFUGs), which have 12,739 households in the watershed (DFO, 2016). Phewa Lake holds a great value but is vulnerable due to various threats such as sedimentation, eutrophication, and encroachment. The lake area and its depth have decreased as a result of these problems which occurred due to poor management of the upstream area. The study area has scattered settlements of Gurung, Tamang, Magar, Thakali, Newar, Brahmin, Chettri and Dalit ethnic groups.

\section{Data Collection}

This study can be considered as an effort to promote PES scheme and sediment retention program in the Phewa watershed. Prior to data collection, oral consents were acquired from respondents for the study involving human research subjects. The oral consents were acquired from the participating households and stakeholders. This study was based on three types of social survey designs: 137 household surveys, 5 stakeholder consultations and 25 key informants interviews (KII). In total, 137 households were selected purposively for household survey; out of them 90 respondents were upstream land managers and the rest were downstream beneficiaries. Due to large and unknown population size and time limitation, purposive sampling was conducted to collect data from household survey. For household survey, 15 residents from each site (Pumdi Bhumdi, Chapakot, Bhadaure Tamagi, Dhikur pokhari, Kaskikot and Sarangkot) were interviewed face-toface with structured questionnaire. We approached the household head for the survey and in case of absence of household head, an available adult was approached. Similarly, downstream beneficiaries (seven wards of the 
southwest part of the PMC) included people involved in various lake-related occupations like hotels (17), fishing (5), boating (6), travel agencies (4), shop keepers (7) and agricultural production (8). The stakeholder consultations were mainly targeted to the stakeholders from all surrounding villages of watershed area. Four stakeholder consultations were undertaken in Chapakot, Dhikur pokhari, Bhadaure Tamagi, and Kaskikot, which covered relevant stakeholders of rural municipality. Similarly, fifth stakeholder consultation was undertaken in PMC, ward Nos. 25 and 26, which covered relevant stakeholders of PMC. For KII, we visited different government and non-government offices to assess the ecosystem services of Phewa Lake. Stakeholder consultations and KII were mainly conducted to explore the opportunities and challenges of PES scheme in Phewa Lake.

A questionnaire was prepared to collect data to examine residents' perception of knowledge of PES. Both open and close ended questions were asked. Respondents of different age, sex, occupation, education levels and residency were surveyed face to face to gather general information to assess their level of awareness regarding participation in PES program and its effectiveness. Snowball sampling technique was applied for the key informant survey because an interview with mid / top level executives of different government and nongovernment organizations was possible only after taking an appointment through personal contacts. The first person (anonymous) to be interviewed was from sediment retention PES program in Phewa watershed. Further connections and information of those interviews were used to discover other organizations, institutions and associations involved in PES design and scheme. Altogether, representatives from 25 small and large organizations directly or indirectly associated with PES program were consulted. Some important organizations were Hydro Power Coordination Committee, Agriculture Service Center, Local Women Networks, District Development Committee, Division Forest Office, District Soil Conservation Office, Hotel Association, Nepal Electricity Authority, Phewa Watershed Management Committee, and Chamber of Commerce.

The study first identified the available ecosystem services of Phewa watershed by asking local communities, business entrepreneurs, local organization, and government organization. Before a list of available services was prepared, relevant literature was reviewed and direct observations of the field were made. Then, a final list of available services was prepared. We consulted with 10 key stakeholders of each rural municipality in order to identify major ecosystem services based on their importance. Among the top selected services, the individual respondents were asked to assign 1 for highly prioritized service and 6 for the least one based on their perception and importance during household survey. The score was then summed to identify the most valuable services for the stakeholders. This was done to rank the 
services with highest importance for respondents in upstream communities and downstream communities (Table 2 and Table 3). The respondents' knowledge and awareness of payment for ecosystem services can influence their decisions on willingness to pay. During the survey, the respondents were asked to vote "Yes" or "No" for the application of PES mechanism. The respondents voted "Yes" to indicate their knowledge and awareness and "No" to indicate their lack of knowledge and awareness of PES and PES policy.

In order to identify major buyers and sellers, five stakeholder consultations (four at rural municipality level and one at district level) were undertaken. The stakeholder consultations were mainly targeted to the stakeholders from all rural municipalities and PMC of watershed area. Also, in order to determine the preferences of the upstream and downstream communities for watershed management, one focus group discussion was held to identify the attributes to be included in the experiment, their current status including the level of change and the community's expectations after the implementation of the PES scheme. It was carried out in participation of community forestry user group, Phewa watershed management committee, and marginalized ethnic communities (communities dependent on forest resource and lake for their livelihood) to collect more information and to know the perception of different classes of community. In addition, secondary data relevant to the study were collected from various records, profiles and report of government, non-government and other line agencies, published papers online portals (Joshi et al., 2020; Timilsina et al., 2020).

\section{Data Analysis}

Descriptive statistics was used to describe the basic features of the results. Trochim (2006) has noted that descriptive statistical analysis offers simple summaries of the sample and the measures. It has also been used to present quantitative descriptions in a concise form, and helps in a sensible way to simplify large quantities of data. In this study, the purpose of descriptive analysis was to sum up the respondent's socio-demographic context. The findings of the descriptive study were illustrated in terms of frequency, percentage, mean and standard deviation. Overall, descriptive statistics clearly and fully explains the results. Technical and policy documents were extensively reviewed to derive existing information. Data were analyzed in a descriptive manner using SPSS (Statistical Package for Social Studies) and Microsoft Excel 13. The location map of the study area was prepared by using ArcGIS (ver.10.2.2) (Joshi et al., 2020).

All interviews and discussions were conducted in Nepali and detailed notes were recorded. The interviews were translated into English and were coded and analyzed in Microsoft Excel. The interviews were coded line by line during open coding and summarized to learn about opportunities and challenges 
of PES scheme in Phewa Lake. Focused coding was done to re-examine open coding before developing theme.

\section{Results}

\section{Socio-economic characteristic of respondents}

As shown in Table 1 below, among the respondents from upstream communities,
$60 \%$ were males and $40 \%$ females, whereas among those from downstream communities, $37 \%$ were males and $63 \%$ females. Similarly, majority (39\%) of people of upstream communities belonged to age class 45-54 followed by $35-44$ age class. In the same way, majority (41\%) of people of downstream communities belonged to age class 45 -

Table 1: Summary of demographic characteristics of sample respondents

\begin{tabular}{|c|c|c|c|c|c|}
\hline \multirow{2}{*}{ Variables } & \multirow{2}{*}{$\begin{array}{c}\text { Factors/ } \\
\text { Levels }\end{array}$} & \multicolumn{2}{|c|}{ Upstream } & \multicolumn{2}{|c|}{ Downstream } \\
\hline & & Frequency & Percentage & Frequency & Percentage \\
\hline \multirow[t]{2}{*}{ Gender } & Male & 55 & 60 & 17 & 37 \\
\hline & Female & 36 & 40 & 29 & 63 \\
\hline \multirow[t]{6}{*}{ Age (years) } & $18-24$ & 2 & 2 & 4 & 8 \\
\hline & $25-34$ & 17 & 19 & 10 & 22 \\
\hline & $35-44$ & 29 & 32 & 6 & 13 \\
\hline & $45-54$ & 35 & 39 & 19 & 41 \\
\hline & $55-64$ & 5 & 5 & 5 & 10 \\
\hline & $\geq 65$ & 3 & 3 & 3 & 6 \\
\hline \multirow[t]{4}{*}{ Caste } & Brahmin & 31 & 34.10 & 21 & 44.70 \\
\hline & Chetri & 22 & 24.20 & 12 & 26.30 \\
\hline & Janajati & 25 & 27.50 & 7 & 15.80 \\
\hline & Dalit & 13 & 14.30 & 6 & 13.20 \\
\hline \multirow{2}{*}{$\begin{array}{l}\text { Knowledge } \\
\text { on PES }\end{array}$} & Yes & 21 & 23 & 18 & 39 \\
\hline & No & 70 & 77 & 28 & 61 \\
\hline \multirow{4}{*}{$\begin{array}{l}\text { Education } \\
\text { level }\end{array}$} & Illiterate & 18 & 20 & 5 & 10 \\
\hline & Primary school & 29 & 32 & 10 & 21 \\
\hline & SLC & 17 & 19 & 14 & 32 \\
\hline & Above SLC & 27 & 29 & 17 & 37 \\
\hline \multirow[t]{5}{*}{ Occupation } & Agriculture & 44 & 48 & Hotel (9) & 19 \\
\hline & Livestock farming & 7 & 8 & Restaurant (12) & 26 \\
\hline & Govt. job & 11 & 12 & Boating (8) & 18 \\
\hline & Hotel & 24 & 26 & Trekking (11) & 23 \\
\hline & Business & 5 & 6 & Shop (6) & 13 \\
\hline \multirow{5}{*}{$\begin{array}{l}\text { Monthly in- } \\
\text { come (NRS); } \\
110 \text { Nepali } \\
\text { Rupees = \$ } 1\end{array}$} & $0-10,000$ & 35 & 38.3 & 5 & 10.3 \\
\hline & $11,000-20,000$ & 39 & 43.3 & 18 & 40 \\
\hline & $21,000-40,000$ & 17 & 18.3 & 11 & 24.7 \\
\hline & $41,000-80,000$ & 0 & 0 & 7 & 15 \\
\hline & Above 81,000 & 0 & 0 & 5 & 10 \\
\hline
\end{tabular}


54 followed by $25-34$ age class.

The results showed that among the total respondents from upstream communities, $29 \%$ had attained higher education, $52 \%$ had attained education below School Leaving Certificate (SLC) and 20\% were illiterate whereas, $90 \%$ of respondents from downstream communities were literate and only 10 $\%$ respondents were illiterate. Out of total respondents, $23 \%$ from upstream and $39 \%$ from downstream were aware of PES.

In addition, among the total respondents from upstream communities, around in fishing, boating, hotel services, tour operation and shop keeping. The monthly household incomes of $40 \%$ of respondents were distributed at about NRS 11,000- NRS 20,000 in upstream and downstream communities (1US\$ = NRS 116).

\section{Major Ecosystem Services}

From the rigorous discussion with stakeholders, we selected tourism, biodiversity, sediment retention and soil conservation, fish, clean water and hydropower as a major ecosystem services in upstream communities (Table 2).

Table 2: Prioritization of ecosystem services based on upstream communities (Mean value)

\begin{tabular}{|l|c|c|c|c|c|}
\hline \multicolumn{1}{|c|}{ Ecosystem Services } & Kaskikot & BhadaureTamagi & DhikurPokhari & Chapakot & Rank \\
\hline Tourism and landscape beauty & 1.5 & 1.30 & 1.30 & 1.5 & 1 \\
\hline Biodiversity & 2.70 & 2.30 & 2.10 & 2.70 & 2 \\
\hline Sediment retention and soil conservation & 3.20 & 2.60 & 2.70 & 3.20 & 3 \\
\hline Fisheries & 3.60 & 4.50 & 4.10 & 3.60 & 4 \\
\hline Clean water & 4.70 & 4.90 & 4.90 & 4.70 & 5 \\
\hline Hydropower & 5.10 & 5.40 & 5.90 & 5.10 & 6 \\
\hline
\end{tabular}

$48 \%$ were engaged in agriculture, $26 \%$ in hotel business and remaining 26\% in government services, foreign jobs, daily wage earning and other business. Similarly,majority of respondents from downstream communities were engaged
Similarly, tourism and landscape beauty, sediment retention and soil conservation and clean drinking water were the first, second and third major services in the downstream communities (Table 3).

Table 3: Prioritization of ecosystem services based on downstream communities

\begin{tabular}{|l|c|c|c|c|c|}
\hline \multicolumn{1}{|c|}{ Watershed ES } & Mean & SD & Minimum & Maximum & Rank \\
\hline Tourism and landscape beauty & 1.27 & .594 & 1 & 3 & 1 \\
\hline Sediment retention and soil conservation & 2.53 & 1.125 & 1 & 5 & 2 \\
\hline Clean water & 2.87 & 1.060 & 1 & 6 & 3 \\
\hline Biodiversity & 4.47 & 1.187 & 1 & 5 & 4 \\
\hline Irrigation & 4.67 & 1.113 & 3 & 6 & 5 \\
\hline Hydropower & 5.07 & 1.163 & 3 & 6 & 6 \\
\hline
\end{tabular}


Respondents' Knowledge and Awareness of Payment for Ecosystem Services

Regarding respondents' knowledge and awareness of conservation of environmental services and PES mechanism, particularly in Phewa watershed, the respondents were first asked if they knew what environmental services are. More than half of the respondents from both upstream and downstream communities showed awareness of these services (Table 4). In response to the next question whether of PES scheme in Phewa watershed for prosperity of both the communities on one hand and conservation of Phewa watershed on the other.

\section{Respondents' perception and views on payment for ecosystem services}

Perception is an indication of individual's thinking on PES. During the survey, the respondents were asked to state their perception of statements in relation to payment for ecosystem services using Likert Scale. On the Likert Scale, the respondents

Table 4: Respondent's knowledge and awareness

\begin{tabular}{|l|c|c|c|c|}
\hline \multirow{2}{*}{$\begin{array}{c}\text { Knowledge and awareness about ES } \\
\text { and PES }\end{array}$} & \multicolumn{2}{c|}{ Upstream } & \multicolumn{2}{c|}{ Downstream } \\
\cline { 2 - 5 } & Frequency & Percentage & Frequency & Percentage \\
\hline Do you know what environmental services are? \\
\hline Yes & 48 & 53 & 31 & 68 \\
\hline No & 43 & 47 & 15 & 32 \\
\hline Do you know what PES is? & 21 & 23 & 18 & 39 \\
\hline Yes & 70 & 77 & 28 & 61 \\
\hline No & 18 & 10 & 13 & 28 \\
\hline Do you know policies regarding PES & 73 & 90 & 33 & 72 \\
\hline Yes & 80 & 88 & 46 & 100 \\
\hline No & 11 & 12 & & 0 \\
\hline Is PES necessary in Phewa watershed? & \multicolumn{5}{|l}{} \\
\hline Yes & No idea
\end{tabular}

they knew PES and policies regarding PES, majority of the respondents showed unawareness. In order to make them aware, the respondents were briefed about the PES and its importance. The respondents were then asked about the necessity of PES in Phewa watershed. Then, it was observed that both upstream and downstream communities highlighted the necessity stated their level of perception from 1 (agree) to 3 (disagree). Summary of the respondents' perception of PES is shown in table 5.

According to Table 5, 51\% of respondents agreed to pay for the protection of Phewa watershed for their own benefit in future. Similarly, $47 \%$ and $53 \%$ of respondents were willing to 
Table 5: Respondents'perception and views on payment for ecosystem services $(N=137)$

\begin{tabular}{|l|c|c|c|}
\hline \multicolumn{1}{|c|}{ Statement } & \multicolumn{2}{c|}{ Response in \% } \\
\cline { 2 - 4 } & Agree & Neutral & Disagree \\
\hline $\begin{array}{l}\text { Willing to pay to protect Phewa watershed for their own } \\
\text { benefit in future }\end{array}$ & 51 & 30 & 19 \\
\hline Paying landowners under PES scheme & 47 & 39 & 14 \\
\hline Willing to conserve Phewa watershed & 52 & 35 & 13 \\
\hline
\end{tabular}

pay to land owners under PES scheme and to conserve Phewa watershed respectively.

To learn about the perception of paying mechanism, we asked who should pay for the conservation of forest and watershed. Majority of the respondents /upstream users (i.e. $46.20 \%$ ) said that the government, tourism entrepreneurs the government, NEA and DDC) who are benefitted directly and indirectly should pay for the compensation.

Furthermore, in order to combat with the adverse effect (i.e., natural disaster, problem of soil erosion, scarcity of water, sedimentation) and sustain lake Product, following counter measures should be adopted based on respondents.

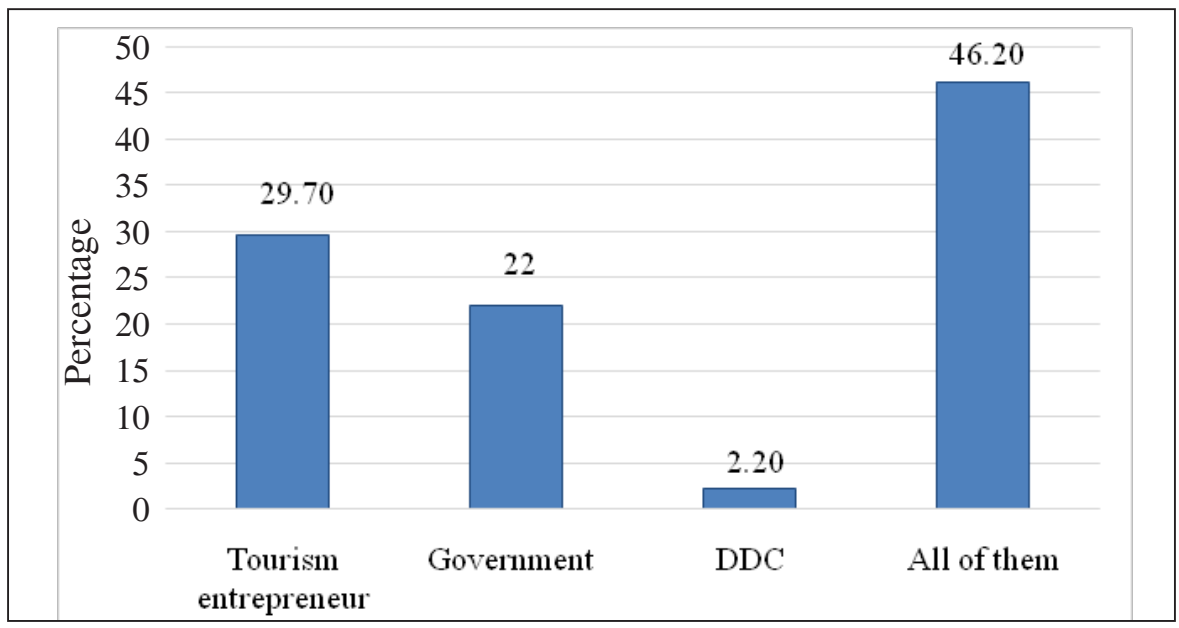

Figure 2 : Compensation provider based on respondents' perception (Percentage)

and District Development Committee (DDC) should pay the compensation; $29.70 \%$ respondents said tourism entrepreneur should pay the compensation; 22 percent respondents said the government should pay; and 2.20 percent said DDC should pay; but the downstream users said that all stakeholders (i.e. tourism entrepreneurs,
According to Table 6, establishment of check dam and gully control, plantation of grass and fodder trees were the respondents' first and second choice for minimizing the impacts on upstream communities respectively. Similarly, establishment of check dam and gully control and conduction of people awareness program were the 
Table 6 : Program necessary for minimizing the adverse effects

\begin{tabular}{|c|l|c|c|}
\hline S.N & \multicolumn{1}{|c|}{$\begin{array}{c}\text { Program necessary for minimizing the adverse } \\
\text { effects }\end{array}$} & $\begin{array}{c}\text { Upstream } \\
(\mathbf{\%})\end{array}$ & $\begin{array}{c}\text { Downstream } \\
(\mathbf{\%})\end{array}$ \\
\hline 1 & Environmental sanitation & 4.4 & 15.8 \\
\hline 2 & Conducting awareness program & 20.2 & 26.3 \\
\hline 3 & Plantation of grass and fodder trees & 26.0 & 23.7 \\
\hline 4 & Establishment of check dam and gully control & 29.8 & 34.2 \\
\hline 5 & Sedimentation dam & 19.6 & - \\
\hline
\end{tabular}

first and second choice in downstream communities. They did not respond to the issue of sedimentation dam and regarded it as the last choice.

\section{Major Sellers, Buyers, and} Intermediaries of Sediment Retention PES Scheme in Phewa Watershed

Suppliers of ecosystem services identified during the field survey are: upstream communities (private land and community land), Panchase protected forest, community forest owner, private land owner and farmer, and agribusiness farmers' institution.

Buyers are the actual users of ecosystem services in user financed PES scheme and buyers are a third party (government, NGO or international agencies) in public financed PES scheme. The identified buyers in Phewa watershed are: Hotel Association of Nepal, Travel Agencies, Trekking Agencies Association of Nepal, Restaurant and Bar Association, Nepal, Phewa Boater Association, Pokhara Chamber of Commerce and Industry, Ward Citizen Forum from Municipality, Paragliding Company, Trekking Shop, Wine Shop, Mobile Shop, Tattoo House, Local Stakeholder /user, Government Institution, Non-
Governmental Institutions, International Institute, Nepal Eelectricity Authority and Drinking Water User.

Intermediaries can be negotiators or agents to link the buyers and sellers, provide legal and advisory inputs to help establish a transparent basis for the transaction between the buyers and sellers. This group can play a pivotal role in building trust between the buyers and sellers. Pokhara Metropolitan, Annapurna Rural Municipality, Division Forest Office, Soil Conservation Office, Agriculture Development Office, Department of Road, Women and Children Office, Institute of Forestry, Nepal Tourism Board, WWF Nepal, Hariyo Ban Program and Federation of Community Forest User Nepal can play such intermediary roles.

\section{Discussion}

Opportunities of Payment for Ecosystem Services in Phewa Watershed

Sufficient investment in the Phewa watershed can produce about 250 tons of fish which would address nutritional demand and provide income generating opportunities to local people (Singh, 
2013). Panchase area is a source of drinking water for Chapakot, Dhikur Pokharai, Bhadaure Tamagi and Pumdi Bhumdi villages where as catchment irrigates these villages. The investment in sustainable development and compensation for local livelihoods can induce rural development (Postel and Thompson, 2005). People are willing to pay $1 \%$ of their profits, an incentive to raise revenue whereas (Khanal and Regmi, 2015) have reported that people of Phewa watershed are willing to pay more than they pay for coping strategies, which they deduced to be $1 \%$ of average monthly income. A similar study conducted in Bolivia showed that the stakeholders desire to pay for quality water supply to support watershed conservation in a developing country (Shultzand Soliz, 2007). However, it is complex to collect and incorporate it into the management scheme.

Individual understanding of the importance of PES influences stakeholders' participation for the effective implementation. Most of the interviewees did not want to participate until PES was described. The knowledge made individuals more sensitive and encouraged them to respond to WTP related questions. Also, the field observation showed that most upstream communities were unaware of the payment for ecosystem services. This means local NGOs, hotels, travel agencies and Phewa Watershed Management Committee will play a bridging role in building awareness among people to facilitate their involvement. The motivation for upstream communities to participate involves financial as well as nonfinancial benefits such as enhanced land protection, enhanced natural resources and improved the lake productivity (Bremer et al., 2014). Bhandari et al. (2018) have stated that upstream area of this watershed can be one of the best eco-tourism destinations for people who come to visit Pokhara. Phewa Watershed has high aesthetic value and it has HarpanKhola, Pame, PPF, Shantistupa, and Sarangkotas important tourist destinations. It has high potential to generate income by developing an eco-friendly picnic spot (Fleming and Fleming, 2009; Paudyal et al., 2018)

The Phewa watershed spread on part of ARM and PMC. Municipalities pass the fund to the wards to reimburse local institutions such as farmers' groups or community forest users' groups or water users' groups who are actively interested in conservation of watershed. The decision-making process is decentralized through District Coordination Committee and Municipalities and it is important to reinforce these institutions to ensure participatory decision making, which is transparent and responsive to the development process (Shultz and Soliz, 2007; Maskey and Wallman, 2008). Resource allocation equity, good governance and monitoring of resource distribution are the potential challenges of this process. But as a local agency, Phewa Watershed Board will play a major role in enforcing land-use policies, connecting farmers or community to access compensation 
funds, and monitoring the process. Similarly, capacity building to promote engagement and incorporate local values encourages collaboration between local people and other managers; the result is successful and creates an environment that fosters dialogue and solutions rather than litigation. Training and education to encourage their successful involvement is therefore another essential move for promoting investment. For capacity building of the local people, it is necessary to recognize their needs which should be fulfilled for sustainable management of Phewa watershed.

\section{Challenges Associated with the PES Scheme in Phewa Watershed}

This study shows that citizens are less conscious of the PES mechanism and lack of capacity to enforce the system. The implementation of such scheme will serve as a challenge for the community. In general, the implementation of the PES scheme should include knowledge of PES scheme, process/method of designing PES schemes and buyer and seller. Limited of knowledge can lead to misunderstanding, uncertainties and distrusting the communities regarding the PES mechanisms. If the challenges are resolved, the society can be encouraged to follow the scheme by promoting of PES mechanism (Richards and Jenkins, 2007). Growing population and rapid urbanization are the driving factors and threats to sustainable resource management. These driving forces put pressure on available services in the Phewa valley such as drinking water supply, irrigation and, consequently, rising demand for the services. The population of the Phewa watershed constitutes 1.9 million national population, with an average density of 665 persons per $\mathrm{km}^{2}$. Rapid urbanization has created pressure on infrastructure and services (CBS, 2011). Examples from around the world have shown that direct payments from beneficiaries of various watershed ecosystem services are a reliable source of investment. For instance, the development of a trust fund in Quito, to compensate land owners for safeguarding water supply, faces financial constraints and equity problems. The fund came voluntarily from water suppliers, non-governmental organizations and electricity authorities. Similarly, the Costa Rican government compensating land owners for watershed services through a forest protection act also faced the same issues as the sources of reimbursement were tax on fossil fuel levy, loan from World Bank, GEF grant and carbon credit sales. Ultimately, both of these cases showed that the direct payments from user fees are a longer term solution than raising funds from indirect sources (Postel and Thompson, 2005).

The estimated WTP does not accurately represent the willingness of beneficiaries to pay. For example, the survey for this study reveals that two interviewees whose income level ranges from $\$ 100$ 125 per month are willing to pay the same as two interviewees earning \$ 500-1000 per month. Other examples are: students and housewives are more likely to volunteer than pay in cash; 
men are less willing to pay than women are. A question, therefore, is whether the WTP really represents capability or just a desire. One must be cautious about integrating the WTP into a policy as it is largely influenced by the level of income, initial bid amount, gender and age of beneficiaries (Ojeda et al., 2008).

Policy gaps and local disagreements were observed as impediment factors for the effective implementation of sediment retention PES scheme in Phewa watershed. However, through the second amendment to the Forest Act 1993, Nepal's government allowed four types of environmental services:carbon sequestration, biodiversity conservation, hydrological cycle, and ecotourism. Other legislations relevant to different climate implicitly promote incentives to produce ecosystem resources. However, no specific policy and guidelines have been prepared for institutionalization of PES mechanism at national level (Bhatta et al., 2018).

Uncertainties and threats associated with the effect of climate change are flooding and landslides (Godar Chhetri, 2012). As Phewa watershed lies in the mid-hills, these risks and uncertainties threaten its sustainability. The Global Circulation Model (GCM) projected an annual growing trend in temperature and precipitation for Nepal in years 2050 and 2100 and the effects of landslides, floods and sedimentation would be most vulnerable for water supply (Agrawala et al., 2003). This will further exacerbate downstream water scarcity as well as adversely affect upstream agricultural and rural livelihoods. Thus, Phewa watershed and its neighboring communities must take these potential uncertainties and threats into account in order to implement successful adaptation strategies that protect downstream water resources and upstream livelihoods.

\section{Conclusion}

The people residing in Phewa watershed are benefitted with multiple goods and services; tourism and landscape beauty, sediment retention and soil conservation, clean water, biodiversity, irrigation, hydropower, fisheries, etc. Panchase protected forest, community forest, private land owner and farmers of upstream area were found to be service provider whereas hotel association, travel agencies, trekking agencies, restaurant, and bar association, boat and fish association, paragliding company, governmental, and non-governmental institution, and electricity authority were downstream beneficiaries. Collectively tourism and landscape beauty were found to be the most important ecosystem services and the local communities were willing to pay $1 \%$ of their monthly income. Tourism promotion, sustainable lake conservation, livelihood improvement, drinking water supply, and hydro power generation were the common findings towards payment opportunities for ecosystem services. However, empowerment of local communities is equally essential to improve local livelihoods and biodiversity conservation through PES mechanism. 
Establishing an independent institution has been realized as the first step to regulate PES mechanism for ensuring sustainable conservation of Phewa watershed and optimizing benefits to stakeholders in win-win situation. Wise implementation of PES scheme has potentiality for enhancing livelihood of upstream and downstream communities and managing Phewa watershed in sustainable manner. So, we suggest policy makers/environment agencies/ local community to materialize study findings for developing guidelines in order to mainstream PES scheme for the betterment of Phewa watershed.

\section{Conflict of Interest}

The authors declare no conflicts of interest.

\section{References}

Agrawala, S., Raksakulthai, V., Van Aalst, M., Larsen, P., Smith, J. and Reynolds, J. 2003. Development and climate change in Nepal: Focus on water resources and hydropower (pp. 1428). Paris: Oecd.https://search.oecd. org/env/cc/19742202.pdf

Aryal, K., Bhatta, L.D., Thapa, P.S., Ranabhat, S., Neupane, N., Joshi, J., Shrestha, K. and Shrestha, A.B. 2019. Payment for ecosystem services: could it be sustainable financing mechanism for watershed services in Nepal? Green Finance, 1(3), p.221. doi: 10.3934/GF.2019.3.221

Bhandari, U., Khadka, R., and Kanel, K. R. 2018. Valuation of Ecosystem Services: A Case of Panchase Pretected Forest in Nepal. http://www.journalajst.com

Bhatta, L.D., Van Oort, B.E.H., Rucevska, I. and Baral, H. 2014. Payment for ecosystem services: possible instrument for managing ecosystem services in Nepal. International Journal of Biodiversity Science, Ecosystem Services \& Management, 10(4), pp.289-299. https://doi.org/10.1080/21513732.2014. 973908

Bhatta, L.D., Khadgi, A., Rai, R.K., Tamang, B., Timalsina, K. and Wahid, S. 2018. Designing community-based payment scheme for ecosystem services: a case from Koshi Hills, Nepal. Environment, development and sustainability, 20(4), $\quad$ pp.1831-1848.https://doi. org/10.1007/s10668-017-9969-x

Bremer, L.L., Farley, K.A. and Lopez-Carr, D. 2014. What factors influence participation in payment for ecosystem services programs? An evaluation of Ecuador's SocioPáramo program. Land use policy, 36, pp.122-133. https://doi. org/10.1016/j.landusepol.2013.08.002

CBS. 2011. National Population and Housing Census, National Report. Government of $\mathrm{Ne}$ pal. Kathmandu.

Costanza, R., De Groot, R., Sutton, P., Van der Ploeg, S., Anderson, S. J., Kubiszewski, I., and Turner, R. K. 2014. Changes in the global value of ecosystem services. Global environmental change, 26, 152-158.

Costanza, R., d'Arge, R., De Groot, R., Farber, S., Grasso, M., Hannon, B., ...\& Van Den Belt, M. 1997. The value of the world's ecosystem services and natural capital. nature, 387(6630), 253-260.

Devkota, S., Shakya, N., Sudmeier, K., McAdoo, B., and Jaboyedoff, M. 2018. Predicting soil depth to bedrock in an anthropogenic landscape: a case study of Phewa Watershed in Panchase region of Central-Western Hills, Nepal. Journal of Nepal Geological Society, 55(1), 173-182. https://doi.org/10.3126/jngs. v55i1.22809

DFO. 2016. Community Forestry database. District Forest Office (DFO), Kaski, Pokhara, Nepal

Fauzi, A. and Anna, Z., 2013. The complexity of the institution of payment for environmental services: A case study of two Indonesian PES schemes. Ecosystem Services, 6, pp.54-63.

Fleming, B. and Fleming, J.P. 2009. A watershed conservation success story in Nepal: Land use changes over 30 years. Himalayan Journal of Development and 
Democracy, 28(1), pp.29-46.https://doi. org/10.3362/1756-3488.2009.004

GodarChhetri S. 2012. Climate change, its impacts on rural livelihood: Adaptation strategies from Siwalik to Terai region. Lambert Academic Publishing.

Gómez-Baggethun, E., De Groot, R., Lomas, P. L., and Montes, C. 2010. The history of ecosystem services in economic theory and practice: from early notions to markets and payment schemes. Ecological economics, 69(6), 1209-1218. doi:10.1016/j.ecolecon.2009.11.007

Joshi, G., Neupane, B., Dahal, D., Shrestha, S.,Dhakal, P., Jandug, C. M. B., and Gautam, D. 2020. Assessment of human-wildlife conflict in Kailali district of Nepal. Journal of Animal Diversity, 2(3), 24-36. https://doi.org/10.29252/JAD.2020.2.3.5

Kanel, K.R. 2010. Application of Economic Valuation Tool: Case Studies from Nepal (Phewa Lake and Ghodaghodi Lake). Conservation and Sustainable Use of Wetlands in Nepal, UNDP.

Khanal, K.P. and Regmi, S.K. 2015. Enhancing ecosystem services through sediment retention in Phewa Lake of Western Nepal. International Conference on Climate Change Innovation and Resilience for Sustainable Livelihood, p.76.http://climdev15.org

Khatri, D.B. 2009. Compromising the environment in payments for environmental services? An institutional analysis of mechanisms for sharing hydroelectricity revenue in Kulekhani watershed, Nepal. Unpublished master's thesis, Graduate School of Development Studies, International Institute of Social Studies: The Hague, The Netherlands.

Kolinjivadi, V., Grant, A., Adamowski, J. and Kosoy, N. 2015. Juggling multiple dimensions in a complex socio-ecosystem: The issue of targeting in payments for ecosystem services. GeoForum, 58, pp.1-13.http://dx.doi.org/10.1016/j. geoforum.2014.10.004

Kunwar, K.J. 2008. Payment for Environmental Services in Nepal (A Case Study of Shivapuri National Park, Kathmandu, Nepal). Nepal Journal Online.
The Initiation, 2(1), pp.63-72.DOI: https://doi.org/10.3126/init.v2i1.2525

Lamichhane, D.B. 2000. Phewa Lake Watershed Area: settlement and environmental Appraisal. pub. , lakeside, Baidam, Pokhara, Nepal.

Leibundgut, G., Sudmeier-Rileux, K., Devkota, S., Jaboyedoff, M., Derron, M.H., Penna, I. and Nyuyen, L. 2016. Rural earthen roads impact assessment in Phewa watershed, Western region, Nepal. Geoenvironmental Disasters 3: 13. doi: 10.1186/s40677-016-0047-8

MEA, 2005. Ecosystems and human well-being: Synthesis Washington (dc) island press.

Pagiola, S. 2008. Payment for Environment Services in Costa Rica', Ecological Economics (65(4): 712-724.

Pagiola, S., Von Ritter, K. and Bishop, J. 2004. Assessing the economic value of ecosystem conservation. World Bank, Environment Department

Paudyal, K., Baral, H., Putzel, L., Bhandari, S. and Keenan, R.J. 2017. Change in land use and ecosystem services delivery from community-based forest landscape restoration in the Phewa Lake watershed, Nepal. International Forestry Review, 19(4), pp.88-101.https://doi. org/10.1505/146554817822330524

Paudyal, K., Putzel, L., Baral, H., Chaudhary, S., Sharma, R., Bhandari, S., Poudel, I. and Keenan, R.J. 2017. From denuded to green mountains: process and motivating factors of forest landscape restoration in Phewa Lake watershed, Nepal. International Forestry Review, 19(4), pp.75-87.DOI: https://doi. org/10.1505/146554817822330515

Paudyal, K., Baral, H. and Keenan, R.J. 2018. Assessing social values of ecosystem services in the Phewa Lake Watershed, Nepal. Forest policy and economics, 90, pp.67-81.https://doi.org/10.1016/j. forpol.2018.01.011

Paudyal, K., Baral, H., Bhandari, S.P., Bhandari, A. and Keenan, R.J. 2019. Spatial assessment of the impact of land use and land cover change on supply of ecosystem services in Phewa 
watershed, Nepal. Ecosystem Services, 36, p.100895.https://doi.org/10.1016/j. ecoser.2019.100895

Postel, S.L. and Thompson Jr, B.H. 2005. Watershed protection: Capturing the benefits of nature's water supply services. In Natural Resources Forum (Vol. 29, No. 2, pp. 98-108). Oxford, UK: Blackwell Publishing, Ltd.https://doi.org/10.1111/ j.1477-8947.2005.00119.x

Rai, A.K. 2000. Limnological characteristics of subtropical Lakes Phewa, Begnas, and Rupa in Pokhara Valley, Nepal. Limnology, 1(1), pp.33-46. doi:10.1007/s102010070027

Richards, M. and Jenkins, M. 2007. Potential and challenges of payments for ecosystem services from tropical forests. Forestry briefing, 16.

Regmi, R.R. and Saha, S.K. 2015. Impact assessment of land use land cover change on soil erosion status in Phewa Lake watershed of Nepal. International Journal of Current Engineering and Technology, 5(3), pp.1708-1717.http://inpressco. $\mathrm{com} /$ category/ijcet

Shultz, S. and Soliz, B. 2007. Stakeholder Willingness to Pay for Watershed Restoration in Rural Bolivia 1. JAWRA Journal of the American Water Resources Association, 43(4), pp.947-956.doi: 10.1111 /j.17521688.2007.00076.x

Singh, B.K. 2013. Payment for Ecosystem Services (PES) in Phewa Watershed for tourism, Hariyo Ban Program, Kathmandu, Nepal.

Suwal, R.C. 2013. Eco-Tourism in Nepal: A Case Study of Phewa Lake Area, Pokhara: Doctoral dissertation, Central Department of
Economics Tribhuvan University, Kirtipur Kathmandu, Nepal.

Thapa, S.R. 2016. Opportunities and Challenges of Payment for Ecosystem Services: Lamber Academia publishing, Doctoral dissertation, Tribhuvan University.

Timilsina, S., Bhattarai, R., Miya, M., and Gautam, D. 2020. Sissoo, its Pathogenic Constraints and their Management in Nepal: A review. Grassroots Journal of Natural Resources, 3, 1-17.https://doi. org/10.33002/nr2581.6853.03041

Trochim, W.M. 2006. Qualitative measures. Research measures knowledge base, 361, pp.2-16. https://pdfs.semanticscholar.org/ca82/06e94c0beb7d63e10d04131966233f3d2a70.pdf

Vatn, A. 2010. An institutional analysis of payments for environmental services. Ecological economics, 69(6), pp.1245-1252. doi:10.1016/j.ecolecon.2009.11.018

Wunder, S. 2005. Payments for environmental services: Some nuts and bolts. CIFOR Occasional Paper, 42(42), 24.https://doi. org/10.1111/j.1523-1739.2006.00559.x

Wunder, S. 2008. Payments for environmental services and the poor: concepts and preliminary evidence. Environment and development economics, 13(3), pp.279-297. https://doi. org/10.1017/S1355770X08004282

Wunder, S. 2014. Revisiting the concept of payments for environmental services. Ecological Economics, 117, pp.234-243. https://doi. org/10.1016/j.ecolecon.2014.08.016

WWF Nepal. 2014. PES Implementation and Monitoring Plan in Phewa Watershed (Final Report). WWF Nepal-Hariyo Ban Program,`Kathmandu, Nepal. 